\title{
DETERMINATION OF PECTIN CONTENT OF EUCALYPTUS WOOD
}

\section{Berdine Coetzee ${ }^{1}$, Henk A Schols ${ }^{2}$ and Francois Wolfaardt ${ }^{3,4 *}$}

${ }^{1}$ Department of Microbiology and Plant Pathology, University of Pretoria, Lunnon road, Pretoria 0002. South Africa.

2.Laboratory of Food Chemistry, Wageningen University, P.O. Box 8129, 6700 EV Wageningen. The Netherlands.

${ }^{3}$ Sappi Technology Centre, P.O. Box 6. The Innovation Hub. Pretoria 0087. South Africa.

4.Department of Chemical Engineering, University of Pretoria, Lunnon road, Pretoria 0002. South Africa.

${ }^{*}$ Corresponding author.

Sappi Technology Centre, P.O. Box 6. The Innovation Hub. Pretoria 0087. South Africa.

E-mail: francois.wolfaardt@sappi.com.

\begin{abstract}
Very little is known about the occurrence of pectin in wood and it is speculated that between 10 and $40 \mathrm{mg} \mathrm{g}^{-1}$ of wood consists of pectin. The present study aimed to quantify pectin in eucalyptus wood and to determine the influence of tree species, yield potential of the site, tree age class and wood tissue type on its
\end{abstract}


occurrence. Wood was hydrolysed using the Saeman procedure and the neutral and acidic monosaccharides quantified with HPLC. The D-galacturonic acid was the predominant pectic monosaccharide followed by D-galactose, L-arabinose and L-rhamnose. Through the addition of all pectic monosaccharides, it was determined that eucalyptus wood contained between 15.2 and $25.8 \mathrm{mg} \mathrm{g}^{-1}$ pectin. Wood tissue type had a major influence on the total pectin content of the samples. The cambium contained the highest concentration of pectin, reflecting more active growth. These results contribute to the understanding of wood biochemistry and can be useful in the biofuels and paper-making industries.

Keywords: Eucalyptus grandis, E. nitens, pectic monosaccharides, pectin content

\section{Introduction}

Very little is known about the occurrence of the pectic polysaccharides in wood, and woody tissue is often described to consist of cellulose, hemicelluloses and lignin, without referring to pectin as a significant constituent (Fengel and Wegener 1989; Sjöström 1993; Koch 2006). It is speculated that between 10 and $40 \mathrm{mg} \mathrm{g}^{-1}$ of the total dry weight of wood consists of pectin (BeMiller 2001; Peng et al. 2003). To our knowledge, no recent work is available on the isolation of wood pectins and older literature (Anderson 1936; Anderson et al. 1937; Larson 1967; Simson and Timell 1978a, 1978b) does not fully quantify pectins in wood. 
The quantification of pectin is important, since pectic polysaccharides are structural components of all primary cell walls and intercellular regions of plants (Goycoolea and Cárdenas 2003). The difficulties to extract and quantify these polysaccharides are due to the complexity of their chemical structure and their close association with other cell-wall polymers (Rumpunen et al. 2002). Previously, detection and determination of pectins were based on the occurrence and chemistry of D-galacturonic acid (D-GalUA), which is the primary monomer of pectin (Sundberg et al. 1996; Gnanasambandam and Proctor 1999). However, the actual correlation between the D-GalUA content and the total content of extractable pectins can be variable, as it is influenced by differences between species, genotypes and tissue (Massiot and Renard 1997; Thomas et al. 2000). The only available method to analyse and quantify complex polysaccharides in wood, including the pectic polysaccharides, is to determine their constituent monomers. These are obtained through total acid hydrolysis (Garna et al. 2006) or acid methanolysis (Sundberg et al. 1996) of the sample, followed by quantification with HPLC or gas chromatography.

Protocols making use of mild conditions such as acid methanolysis resulted in incomplete cleavage of the glycosidic and glycuronosyl linkages, especially from a robust substrate such as wood (Biermann 1988; Garna et al. 2006). This incomplete hydrolysis may lead to an overestimation of the individual sugars, because oligomers that not only contain the monosaccharide of interest are 
included in the quantification. Total hydrolysis of the sample is, however, achieved when using a strong acid at a high temperature as outlined in the Saeman procedure (Adams 1965; Biermann 1988). The Saeman hydrolysis of pectin-containing material, however, may combine the release of the D-GalUA as a product of hydrolysis and its degradation into lactones (Blake and Richards 1968; Uçar and Balaban 2003; Garna et al. 2006). The total acid hydrolysis of wood thus, results in the more accurate quantification of the monosaccharide, but standards should be subjected to the same hydrolysis conditions to compensate for possible degradation of the released monosaccharides.

Many studies investigated the total monosaccharide composition of hardwood species after hydrolysis (Whiting and Goring 1983; Kaar et al. 1991; Uçar and Balaban 2003; Koch 2006; Brito et al. 2008; Tunc and van Heiningen 2008) and in most cases, cellulose and hemicellulose were considered to be the only source of these monosaccharides. The fact that a considerable portion of these monosaccharides may originate from pectic polysaccharides was ignored as pointed out by Sundberg et al. (1996) and Bertaud et al. (2002).

The occurrence of the pectic polysaccharides in all wood tissues has not been studied to a significant extent. This study, therefore, focused on the quantification of pectin in hardwoods, specifically Eucalyptus grandis and $E$. nitens. An analytical procedure is described to quantify the pectic monosaccharides in wood, including the uronic acids and neutral 
monosaccharides. The concentrations of the pectic monosaccharides were used to calculate the pectin content in different samples.

\section{Materials and methods}

Sampling and preparation of wood samples

Wood cores were sampled at breast height from two eucalyptus species in commercial plantations during the winter of 2006. The wood samples consisted of 36 wood cores from E. grandis and E. nitens from three age classes $(6,10$ and 14 years) grown on sites that were considered to be high and low in terms of potential wood yield. Cores were collected from three randomly selected trees at each site and each tree represented a replication for the experiment. Sections representing three tissue types, namely cambial tissue, sapwood and heartwood were cut from each core. These samples were finely ground into powder, using coarse sandpaper (no. 60), without heating the core in the process. The wood powder was screened and the fraction between $423 \mu \mathrm{m}$ and $635 \mu \mathrm{m}$ used for analysis.

\section{Hydrolysis and sample preparation}

The wood samples (10 to $20 \mathrm{mg}$ ) were hydrolysed with $\mathrm{H}_{2} \mathrm{SO}_{4}$, using the twostep Saeman procedure (Adams 1965; Biermann 1988). After incubation at $30^{\circ} \mathrm{C}$ for $60 \mathrm{~min}$, the internal standard L-fucose (L-Fuc) (Sigma-Aldrich) was added to each tube and further hydrolysed at $100^{\circ} \mathrm{C}$ for $120 \mathrm{~min}$. Standard solutions containing D-galactose (D-Gal), L-rhamnose (L-Rha), L-arabinose (L-Ara) 
(Sigma-Aldrich) and D-GalUA (Fluka) at four concentrations $(0.75,1.25,2.25$ and $3.25 \mathrm{~g} \mathrm{ml}^{-1}$ ) were subjected to both hydrolysis steps to compensate for possible degradation of the wood monosaccharides.

\section{Analytical method}

The monosaccharide composition of the hydrolysates was determined by high performance anion exchange chromatography with pulse amperometric detection (HPAEC-PAD). The separation of the D-GalUA and the neutral monosaccharides was done on a Dionex Ultimate 3000 system with a CarboPAc $^{\circledR}$ PA1 column $(250 \times 4 \mathrm{~mm})$ in combination with a CarboPAc ${ }^{\circledR}$ PA1 guard column (50 x $4 \mathrm{~mm}$ ) (Dionex Corporation, Sunnyvale, California). Samples were kept at $5^{\circ} \mathrm{C}$ until injection $(20 \mu \mathrm{l})$ and analysis were carried out at $30^{\circ} \mathrm{C}$ at a flow rate of $1 \mathrm{ml} \mathrm{min}^{-1}$. Each sample was analysed in two separate runs. During the first run, the neutral monosaccharides were eluted with $10 \mathrm{mM} \mathrm{NaOH}$ for $30 \mathrm{~min}$. The column was then conditioned and equilibrated with $170 \mathrm{mM}$ sodium acetate in $80 \mathrm{mM} \mathrm{NaOH}$ for 60 min prior to the second run during which the uronic acids were analysed. The D-GalUA was eluted with $170 \mathrm{mM}$ sodium acetate in $80 \mathrm{mM} \mathrm{NaOH}$ for $15 \mathrm{~min}$. The pulsed-amperometric detector (PAD) (esa Coulochem III; 5040 analytical cell) settings were $E_{1}=200 \mathrm{mV}, \mathrm{E}_{2}=-1000$ $m V, E_{3}=600 \mathrm{mV}$ and $E_{4}=-100 \mathrm{mV}$ for $500,10,10$ and 40 msec, respectively at a sensitivity of $100 \mathrm{nC}$. The delay time was set at $360 \mathrm{msec}$ at a guard cell potential of $0.0 \mathrm{mV}$. The detector output was digitised by a UCI-50 Universal 
Chromatography interface (Dionex) at a sampling rate of 1 point $\sec ^{-1}$ and analysed using Chromeleon ${ }^{\circledR}$ version 6.80 software (Dionex).

\section{Experimental design and statistical analysis}

A completely randomised experiment was designed with four factors (tree species, yield potential of the site, tree age class and wood tissue type) replicated three times. The data were tested in a $2 \times 2 \times 3 \times 3$ factorial experiment to investigate the influence of the different factors on the occurrence of the pectic monosaccharides and the total pectin content of the eucalyptus samples. The data were subjected to analysis of covariance (ANCOVA) using the correlation analysis (CORR) and general linear modelling (GLM) procedures of the SAS/STAT ${ }^{\circledR} 9.1$ statistical package (SAS Institute Inc., USA) and mean values of replicated measurements compared with Scheffé's test.

\section{Results and discussion}

Separation of monosaccharides

The Saeman procedure resulted in the complete hydrolysis of the wood polysaccharides, since no unidentified peaks were seen on the chromatograms. Monosaccharides including D-glucose (D-Glc), D-mannose (D-Man), D-xylose (D-Xyl), D-Gal, L-Rha, L-Ara as well as D-GalUA was released during hydrolysis. The D-Glc was deemed to originate from the cellulose fraction of the wood (Sundberg et al. 1996), while the D-Man and D-Xyl mainly originated from hemicellulose (Grand-Reid 1997; Rowell et al. 2005). The pectic 
polysaccharides were, therefore, considered to be composed of the remaining monosaccharides, namely D-GalUA, D-Gal, L-Rha and L-Ara. These pectic monosaccharides were accurately quantified in two HPLC runs. Complete separation of the neutral pectic monosaccharides was achieved in the first run with $10 \mathrm{mM} \mathrm{NaOH}$ (Figure 1). In the second run with $170 \mathrm{mM}$ sodium acetate in $80 \mathrm{mM} \mathrm{NaOH}$, complete separation of the uronic acids was achieved, but Dglucuronic acid (D-GlcUA) was not present at detectable levels in any of the samples (Figure 2). Correction factors of 0.90 and 0.88 for the C6 and C5 sugars, respectively, were included in the calculation of the monosaccharide concentrations to compensate for the loss of water during hydrolysis. The contribution of each monosaccharide to the sample was expressed as the mass of the sugar relative to the mass of the wood $\left(\mathrm{mg} \mathrm{g}^{-1}\right)$ and the amount of pectin was then calculated through the addition of the pectic monosaccharides

Occurrence of pectic monosaccharides in wood

The D-GalUA occurred in higher concentrations than the other pectic monosaccharides at an average of $14.4 \mathrm{mg} \mathrm{g}^{-1}$ wood. This value was calculated across all four factors (tree species, yield potential of the site, tree age class and wood tissue type) and had a standard deviation (S.D.) of $4.1 \mathrm{mg} \mathrm{g}^{-1}$. Notably higher concentrations ( 36 to $50 \mathrm{mg} \mathrm{g}^{-1}$ ) were reported to occur in Betula spp. (Sundberg et al. 1996; Koch 2006). In other studies, the total uronic acid content of wood was used to indicate the concentration of D-GalUA. Uronic acid showed values from 36 to $60 \mathrm{mg} \mathrm{g}^{-1}$ (Koch 2006; Garrote et al. 2007). This method, 
however, did not account for the significant amount of D-GlcUA originating from hemicellulose (Grand-Reid 1997; Rowell et al. 2005).

The tested eucalyptus samples contained an average of $3.81 \mathrm{mg} \mathrm{g}^{-1}$ (S.D. $=1.77$ $\mathrm{mg} \mathrm{g}^{-1}$ ) D-Gal and $1.66 \mathrm{mg} \mathrm{g}^{-1}$ (S.D. $=0.59 \mathrm{mg} \mathrm{g}^{-1}$ ) L-Ara. These values were again notably less than the 7.0 to $10.1 \mathrm{mg} \mathrm{g}^{-1} \mathrm{D}$-Gal and 4.0 to $10.0 \mathrm{mg} \mathrm{g}^{-1} \mathrm{~L}$-Ara reported in literature for other hardwoods (Sundberg et al. 1996; Koch 2006).

The L-Rha was the pectic monosaccharide that occurred in the lowest concentrations in the eucalyptus wood and the samples contained an average of $0.80 \mathrm{mg} \mathrm{g}^{-1}\left(\right.$ S.D. $\left.=0.21 \mathrm{mg} \mathrm{g}^{-1}\right)$. This amount was again, notably lower than the values of 3.9 to $6.0 \mathrm{mg} \mathrm{g}^{-1}$ reported to occur in Betula spp. (Sundberg et al. 1996; Koch 2006) and in other hardwoods (Koch 2006).

\section{Total pectin content}

The pectin content of $E$. grandis and E. nitens wood was calculated by adding the total amount of pectic monosaccharides (D-GalUA, L-Rha, L-Ara and D-Gal). The total pectin in the wood varied between 15.2 to $25.8 \mathrm{mg} \mathrm{g}^{-1}$ of dry wood (Table 1) and these values compared well with estimates of 10 to $40 \mathrm{mg} \mathrm{g}^{-1}$ by and BeMiller (2001) and Peng et al. (2003).

The E. grandis samples with the lowest and the highest concentrations of pectin (15.2 and $25.1 \mathrm{mg} \mathrm{g}^{-1}$, respectively) were collected from a site with a low yield 
potential (Table 1). However, the E. nitens samples with the lowest and highest concentration of pectin of 17.0 and $25.8 \mathrm{mg} \mathrm{g}^{-1}$, respectively, were obtained from the high-yield site. These values did not differ significantly $(p>0.05)$ between species, while the wood tissue type had a significant influence $(p=0.0066)$. The cambial tissue contained significantly more pectin $\left(22.6 \mathrm{mg} \mathrm{g}^{-1}\right)$ than the sapwood (19.2 $\left.\mathrm{mg} \mathrm{g}^{-1}, \mathrm{p}=0.0367\right)$ or heartwood $\left(20.1 \mathrm{mg} \mathrm{g}^{-1}, \mathrm{p}=0.0019\right)$, which did not differ. $(p=0.2803)$. These results, thus, confirm that pectin is closely associated with tissue where active growth occurs (Pallardy and Kozlowski 1997; Verma 2001). The pectin content of the cambial tissue in the current study was much lower than the reported values of 50 to $60 \%$ occurring in aspen and basswood (Simson and Timell 1978a; 1978b). The work of these authors, however, focused on the isolation of pectin from the cambial tissue of very young (less than $10 \mathrm{~cm}$ in diameter), vigorous growing trees, with a high surface to volume ratio. The cambial tissue of the samples also only contained intracellular material and no cells with secondary walls, which was not the case in the current study.

The interaction between potential yield of the site and tree age class was significant $(p=0.0497)$ in terms of the pectin concentration and on low-yield sites, six-year-old trees contained more pectin than older trees (Figure 3). The higher pectin content in the younger trees may reflect more actively growing tissue (Mohnen 1999). A difference between trees of different ages was however, not 
seen at the high-yield sites and may be as a result of more favourable environmental conditions that allow sustained growth of trees at all ages.

\section{Conclusions}

The Saeman procedure (Adams 1965; Biermann 1988) resulted in complete hydrolysis of the wood polysaccharides and was preferred to protocols using milder conditions (Biermann 1988; Sundberg et al. 1996; Garna et al. 2006). The hydrolysis of eucalyptus wood resulted in the release of all pectic monosaccharides as well as monosaccharides originating from cellulose and hemicellulose. Complete separation of the neutral pectic monosaccharides and uronic acids was subsequently achieved with two HPLC runs.

The D-GalUA occurred in the highest concentration of the pectic monosaccharides, reflecting the fact that it is the sole constituent of homogalacturonan (HG) and also $50 \%$ of the rhamnogalacturonan-I (RG-I) backbone. The remainder of the RG-I backbones consisted of L-Rha. The tested samples also contained small quantities of D-Gal and L-Ara, originating from the side-chains of RG-I.

The pectin content of the eucalyptus wood ranged from 15.2 to $25.8 \mathrm{mg} \mathrm{g}^{-1}$. Quantification of pectin in wood through determination of its constituent monomers proved to be suitable for hardwoods. However, this technique cannot be applied for softwoods, since their hemicelluloses consist of 
galactoglucomannan and arabino-4-O-methylglucuronxylan that may contribute to the D-Gal and L-Ara in the hydrolysates (Grand-Reid 1997; Rowell et al. 2005; Kock 2006).

Wood tissue type proved to have a major influence on the total pectin content of the samples. The cambial tissue contained the highest concentrations of pectin, because active growth mainly occurs here (Pallardy and Kozlowski, 1997), thus, reflecting the importance of pectin in developmental processes (Jarvis 1984; Darvill et al. 1992; Weber et al. 1996; Willats et al. 2001). Species did not have a significant influence on the pectin content of samples and E. grandis and $E$. nitens did not differ in their total pectin content. However, the pectin content of more eucalyptus species need be determine before any general conclusions about the relative amounts of pectin across species can be made.

The age of the trees and the yield potential of sites did not influence the pectin content directly, but these factors were involved in one significant interaction. The interaction between the age class of the trees and the yield of the site indicated a possible decrease in the pectin content with an increase in tree age, supporting the fact that actively-growing wood contains more pectin (Pallardy and Kozlowski 1997; Verma 2001).

Further work should include reconstruction of the pectic domains based on the molar mass of monosaccharides contributing to pectin. A better comprehension 
of the different factors that influence the composition and the structure of the pectin in wood can contribute to the understanding of wood biochemistry. Such information can be especially useful for biomass conversion and fibre utilisation, for the biofuels and paper-making industries, respectively. 


\section{Acknowledgements}

This study was partially funded by the Thrip programme of the South African

Department of Trade and Industry. We thank Dr Mike van der Linde and Prof. Hennie Groeneveld for assistance with statistical analysis of the data.

\section{References}

Adams, G.A. Methods in Carbohydrate Chemistry, Volume V. Academic Press Inc., New York, 1965.

Anderson, E. (1936) The isolation of pectic substances from wood. J. Biol. Chem. 112:531-539.

Anderson, E., Seigle, L.W., Krznarich, P.W., Richards, L., Martney, W.W. (1937) The isolation of pectic substances from wood II. J. Biol. Chem. 121:165-174.

BeMiller, J.N. (2001) Complex Polysaccharides. In: Glycoscience: Chemistry and Chemical Biology. Eds. Fraser-Reid, B.O., Tatsata, K., Thiem, J. Springer, Heidelberg. pp. 1865-1882. 
Bertaud, F., Sundberg, A., Holmbom, B. (2002). Evaluation of acid methanolysis for analysis of wood hemicelluloses and pectins. Carbohydr. Polym. 48:319-324.

Biermann, C.J. (1988) Hydrolysis and other cleavage of glycosidic linkages. In: Analysis of Carbohydrates by GLC and MS. Eds. Biermann, C.J., McGinnis, G.D. CRC Press, Boca Raton. pp. 27-47.

Blake, J.D., Richards, G.N. (1968) Problems of lactonisation in the analysis of uronic acids. Carbohydr. Res. 8:275-281.

Brito, J.O., Silva, F.G., Leão, M.M., Almeida, G. (2008) Chemical composition changes in eucalyptus and pinus woods submitted to heat treatment. Bioresource Technol. 99:8545-8548.

Darvill, A., Augur, C., Bergmann, C., Carlson, R.W., Cheong, J.-J., Eberhard, S., Hahn, M.G., Ló, V.-M., Marfà, V., Meyer, B., Mohnen, D., O’Neill, M.A., Spiro, M.D., van Halbeek, H., York, W.S., Albersheim, P. (1992) Oligosaccharinsoligosaccharides that regulate growth, development and defence responses in plants. Glycobiology 2:181-198. 
Fengel, D., Wegener, G. Wood: Chemistry, Ultrastructure, Reactions. Verlag, Remagen, 1989.

Garna, H., Mabon, N., Nott, K., Wathelet, B., Paquot, M. (2006) Kinetic of the hydrolysis of pectin galacturonic acid chains and quantification by ionic chromatography. Food Chem. 96:477-484.

Garrote, G., Kabel, M.A., Schols, H.A., Falqué, E., Domínguez, H., Parajó, J.C. (2007) Effects of Eucalyptus globulus wood autohydrolysis conditions on the reaction products. J. Agric. Food Chem. 55:9006-9013.

Gnanasambandam, R., Proctor, A. (1999) Preparation of soy hull pectin. Food Chem. 65:461-467.

Goycoolea, F.M., Cárdenas, A. (2003) Pectins from Opuntia spp.: A short review. J. PACD 10:17-29. 
Grand-Reid, J.S. (1997) Carbohydrate metabolism: Structural carbohydrates. In: Plant Biochemistry. Eds. Day, P.M., Harbone, J.B., Bonner, J.F. Academic Press, New York. pp. 205-236.

Jarvis, M.C. (1984) Structure and properties of pectin gels in plant cell walls. Plant, Cell Environ. 7:153-164.

Kaar, W.E., Cool, L.G., Merriman, M.M., Brink, D.L. (1991). The complete analysis of wood polysaccharides using HPLC. J. Wood Chem. Technol. 11:447-463.

Koch, G. (2006) Raw material for pulp. In: Handbook of Pulp. Ed. Sixta, H. WILEY-VCH Verlag GmbH and Co. KGaA, Weinheim. pp. 21-68.

Larson, K.C. An investigation of pectic substances in the developing xylem of Populus tremuloides. Ph.D Thesis. Institute of Paper Chemistry, Wisconsin, 1967. 
Massiot, P., Renard, C.M.G.C. (1997) Composition, physico-chemical properties and enzymatic degradation of fibres prepared from different tissues of apple. Lebensm. Wiss. Technol. 30:800-806.

Mohnen, D. (1999) Biosynthesis of pectins and galactomannans. In: Comprehensive Natural Products Chemistry Volume III. Eds. Barton, D., Nakanishi, K., Meth-Cohn, O. Elsevier Science, Amsterdam. pp. 497-527.

Pallardy, S.G., Kozlowski, T.T. Physiology of Wood Plants. Academic Press, San Diego, 1997.

Peng, F., Ferritsins, R., Ãngsâs, U. 2003 Mechanical pulping with pectinase pretreatment of wood chips. In: Proceedings of the International Mechanical Pulping Conference. pp. 335-340.

Rowell, R.M., Petterson, R., Han, J.S., Rowell, J.S., Tshabalala, M.A. (2005) Cell wall chemistry. In: Handbook of Wood Chemistry and Wood Composites. Ed. Rowell, R.M. CRC Press, Boco Raton. pp. 35-76. 
Rumpunen, K., Thomas, M., Badilas, N., Thibault, J.-F. (2002) Validation of a combined enzymatic and HPLC method for screening of pectins in fruits of Japanese quince (Chaenomeles japonica). Lebensm. Wiss. Technol. 35:490-496.

Simson, B.W., Timell, T.E. (1978a) Polysaccharides in cambial tissues of Populus tremuloides and Tilia americana I. Isolation, fractionation, and chemical composition of the cambial tissue. Cell. Chem. Technol. 12:39-50.

Simson, B.W., Timell, T.E. (1978b) Polysaccharides in cambial tissues of Populus tremuloides and Tilia americana IV. 4-O-methylglucuronoxylan and pectin. Cell. Chem. Technol. 12:79-84.

Sjöström, E. Wood Chemistry: Fundamentals and Applications. Academic Press Inc., San Diego, 1993.

Sundberg, A., Sundberg, K., Lillandt, C., Holmbom, B. (1996) Determination of hemicelluloses and pectins in wood and pulp fibres by acid methanolysis and gas chromatography. Nord. Pulp Pap. J. 4:216-226. 
Thomas, M., Crépeau, M.J., Rumpunen, K., Thibault, J.-F. (2000) Dietary fibre and cell-wall polysaccharides in the fruits of Japanese quince (Chaenomeles japonica). Lebensm. Wiss. Technol. 33:124-131.

Tunc, M.S., van Heiningen, A.R.P. (2008) Hemicellulose extraction of mixed southern hardwood with water at $150{ }^{\circ} \mathrm{C}$ : Effect of time. Ind. Eng. Chem. Res. 47:7031-7037.

Uçar, G., Balaban, M. (2003) Hydrolysis of polysaccharides with $77 \%$ sulphuric acid for quantitative saccharification. Turk. J. Agr. Forest. 27:361-365.

Verma, D.P.S. (2001) Cytokinesis and building of the cell plate in plants. Annu. Rev. Plant Physiol. Plant Mol. Biol. 52:751-784.

Weber, J., Olsen, O., Wegener, C., von Wettstein, D. (1996) Digalacturonates from pectin degradation induce tissue responses against potato soft rot. Physiol. Mol. Plant. Path. 48:389-401. 
Whiting, P., Goring, D.A.I. (1983) The composition of the carbohydrates in the middle lamella and secondary wall of tracheids from black spruce wood. Can. J. Chem. 61:506-508.

Willats W.G.T., McCartney, L., Mackie, W., Knox, J.P. (2001) Pectin: Cell biology and prospects for functional analysis. Plant Mol. Biol. 47:9-27. 
Table 1 The pectin content $\left(\mathrm{mg} \mathrm{g}^{-1}\right)$ measured in different wood samples from two eucalyptus species.

\begin{tabular}{cccccc}
\hline \multirow{2}{*}{$\begin{array}{c}\text { Tree } \\
\text { age }\end{array}$} & \multirow{2}{*}{ Wood tissue } & $\begin{array}{c}\text { High-yield } \\
\text { site }\end{array}$ & $\begin{array}{c}\text { Low-yield } \\
\text { site }\end{array}$ & $\begin{array}{c}\text { High-yield } \\
\text { site }\end{array}$ & $\begin{array}{c}\text { Low-yield } \\
\text { site }\end{array}$ \\
\hline \multirow{3}{*}{6 yrs } & Cambium & 20.5 & 25.1 & 21.8 & 24.4 \\
& Sapwood & 17.7 & 22.8 & 21.6 & 19.3 \\
& Heartwood & 17.2 & 21.1 & 21.8 & 23.0 \\
& Cambium & 20.1 & 24.8 & 24.6 & 19.9 \\
10 yrs & Sapwood & 18.9 & 18.0 & 18.1 & 16.6 \\
& Heartwood & 22.8 & 19.6 & 25.8 & 17.3 \\
& Cambium & 24.6 & 23.3 & 22.4 & 19.2 \\
& Sapwood & 22.3 & 20.4 & 17.0 & 18.3 \\
& Heartwood & 19.8 & 15.2 & 17.0 & 21.4 \\
\hline
\end{tabular}




\section{Captions for figures}

Figure 1 HPAEC-PAD chromatogram of the hydrolysate of a wood sample that was diluted (1:3) indicating L-fucose (internal standard), L-rhamnose, Larabinose and D-galactose, eluted with $10 \mathrm{mM} \mathrm{NaOH}$. The retention times of $\mathrm{D}$ glucose and the combined peak of D-xylose and D-mannose was at 17.5 and 20.5 min, respectively.

Figure 2 HPAEC-PAD chromatogram of the hydrolysate of a wood sample indicating D-galacturonic acid when eluted with $170 \mathrm{mM}$ sodium acetate in 80 $\mathrm{mM} \mathrm{NaOH}$.

Figure 3 Influence of the yield potential of a site and tree age class on the pectin content of eucalyptus trees (bars for each site with the same letters do not differ significantly, Scheffé's test, $p \leq 0.05$ ) 


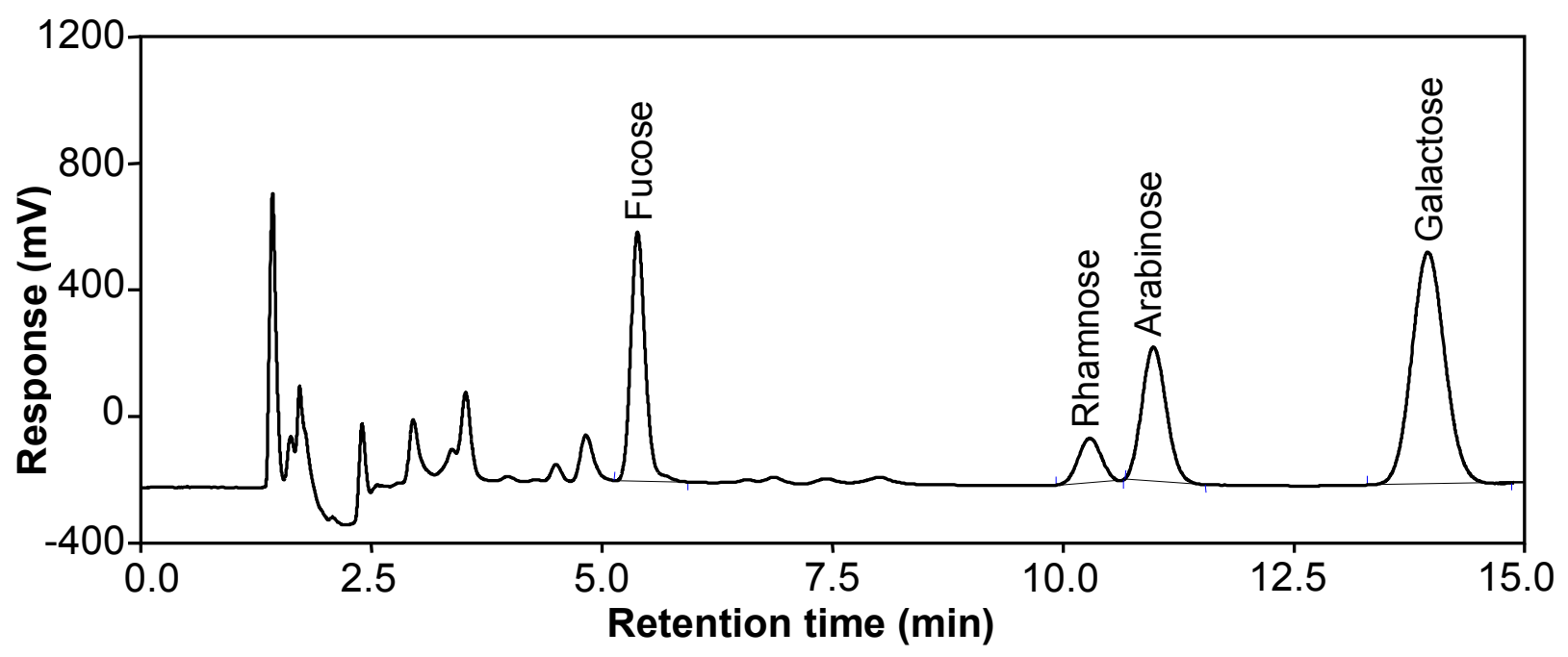

Figure 1 


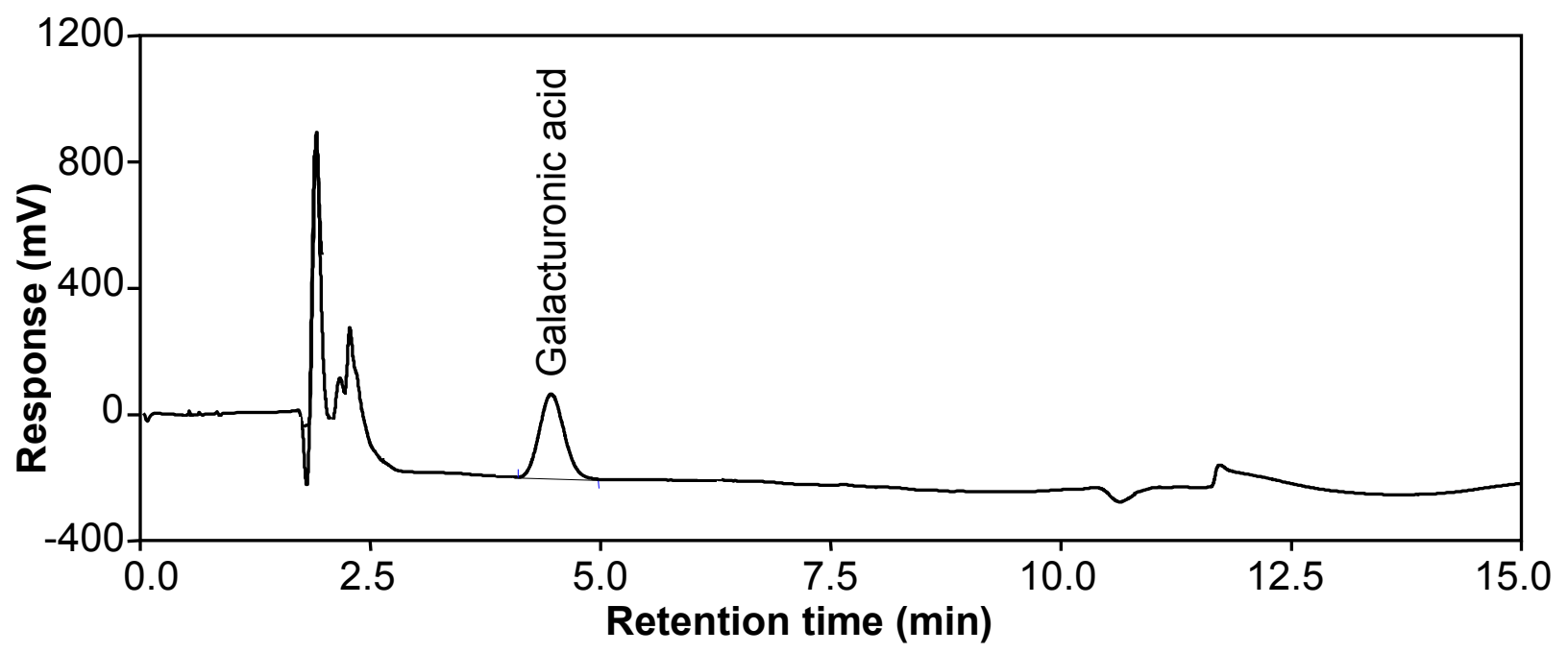

Figure 2 


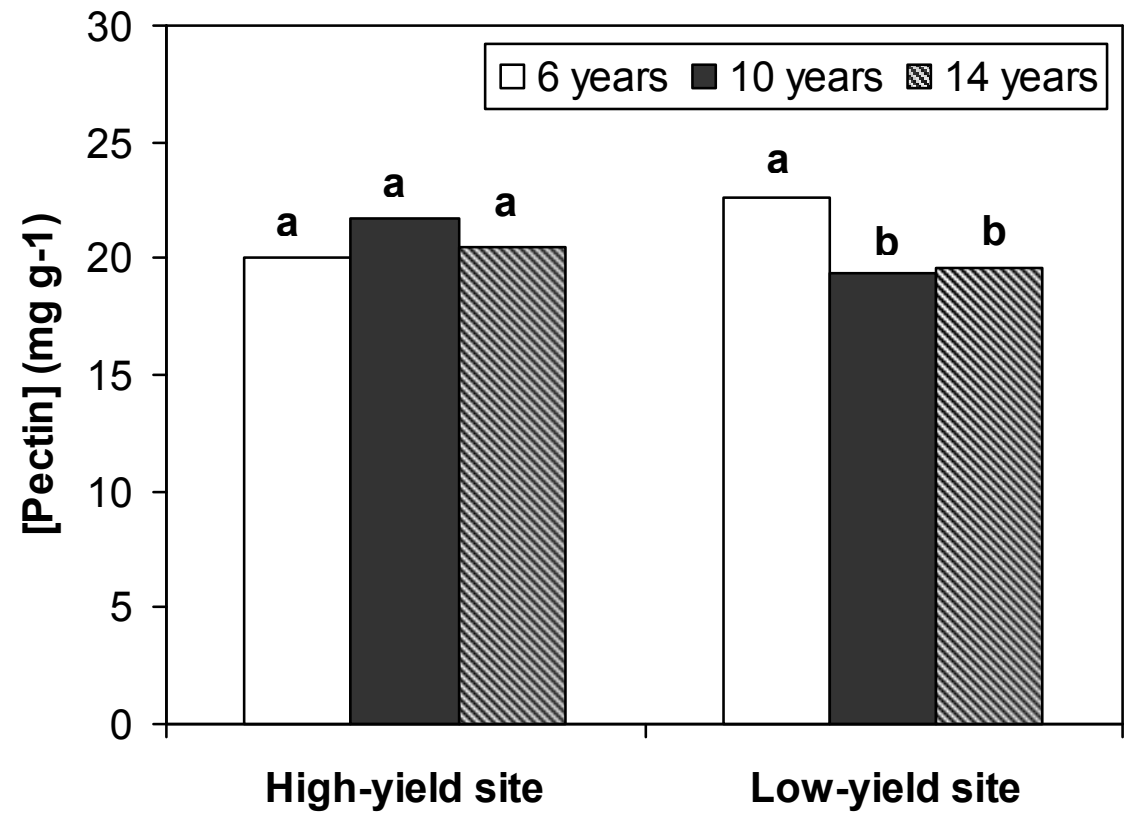

Figure 3 